ROCZNIKI TEOLOGICZNE

Tom LXVIII, zeszyt $10-2021$

DOI: https://doi.org/10.18290/rt.216810.5

ANDRZEJ SZYMAŃSKI

\title{
UPRAWIANIE HAZARDU WŚRÓD PIŁKARZY ŚLĄSKIEJ IV LIGI A ICH STAN CYWILNY
}

\section{GAMBLING AMONG THE PLAYERS OF THE 4TH LEAGUE OF SILESIA REGION} AND THEIR MARITAL STATUS

\begin{abstract}
A b s t r a c t. The research describes the phenomenon of gambling in a group of 583 footballers playing in the 4th league of the Silesian microregion. The objectives of the study were to identify the participation of footballers in gambling and to find an answer to the question whether, due to their marital status, athletes who are in formal relationships differ from players who are not in such relationships in the way of approaching the game. The research was carried out using the proprietary questionnaire, which was extended to the Canadian Gambling Games Index CPGI. The obtained results indicate that the respondents statistically more often engaged in gambling than the average Pole over 15 years old. A preferred form of game among the surveyed players was participation in betting on bookmakers. Footballers are at increased risk of becoming addicted to gambling. This problem affects over $12 \%$ of the surveyed players. An important predictor of gambling by footballers was their active contact with the game in childhood. Research shows that players who are married are more cautious about gambling than their colleagues in informal or single relationships.
\end{abstract}

Keywords: behavioral addictions; gambling; footballers; marital status.

\section{WPROWADZENIE}

Od momentu swojego powstania ludzkość zmaga się z licznymi zagrożeniami i niedogodnościami. Występujące trudności i niebezpieczeństwa mają

Dr ANDRZEJ SZYMAŃSKI - Katedra Bezpieczeństwa Wewnętrznego, Akademia Wychowania Fizycznego im. Jerzego Kukuczki w Katowicach; adres do korespondencji: 40-065 Katowice ul. Mikołowska 72A; e-mail: a.szymanski@awf.katowice.pl, ORCID: https://orcid.org/ 00000002-3787-6474. 
przy tym różny swój zasięg, charakter i genezę. Niektóre z nich są wynikiem świadomej aktywności człowieka. Inne stanowią pochodną sił natury bądź są funkcją czynników o identyfikowanym rodowodzie jako łańcucha splotu nieszczęśliwych wypadków. Swoim oddziaływaniem obejmują one pojedyncze osoby, większe grupy, a często całe społeczeństwa.

W przypadku androgenicznych mechanizmów powstawania problemów i zagrożeń ich źródeł można doszukać się w uwarunkowaniach politycznych, braku respektowania praw jednostki oraz w swoistej naturze ludzkiego postępowania. Ich siłą napędową są nierówności społeczne, źle pojęty dobrobyt, chęć podporządkowania sobie wszystkiego i wszystkich czy też umiłowanie człowieka do przyjemności i zachowań ryzykownych. W tym ostatnim kontekście coraz częściej mówi się i pisze o szkodliwym zachowaniu dotyczącym uzależniania się od czynności (uzależnieniu behawioralnym) ${ }^{1}$. Zawraca się równocześnie uwagę na występujące analogie w mechanizmach powstawania uzależnień od czynności i uzależnień od substancji ${ }^{2}$.

Charakter i skala uzależnień od czynności stały się wyzwaniem dla wielu specjalistów, którzy w swojej praktyce coraz częściej spotykają się z osobami wykazującymi problemy w tym obszarze ${ }^{3}$. Do grupy tego typu zjawisk zalicza się m.in. uzależnienie od hazardu. W literaturze na określenie jego zaburzonej formy spotkać można takie terminy, jak: nałogowe uprawianie hazardu (addictive gambling), hazard problemowy (problem gambling), hazard kompulsywny/przymusowy (compulsive gambling) czy hazard patologiczny (pathological gambling $)^{4}$. Nie przesądzając, która ze wskazanych nazw jest najbardziej poprawna, warto odnotować, że patologiczny hazard to zdefiniowane medycznie zaburzenie opisane w klasyfikacji DSM Amerykańskiego Towarzystwa Psychiatrycznego jak i Międzynarodowej Statystycznej Klasyfikacji Chorób i Problemów Zdrowotnych ICD. Odnosi się ono ogólnie do zachowań hazardowych online (przez internet) albo offline, nad którymi gracz traci kontrolę, nadaje im pierwszoplanowość

\footnotetext{
${ }^{1}$ Ewa Krzyżak-Szymańska i Andrzej Szymański, Profilaktyka nowych uzależnień wśród dzieci i młodzieży. Zarys problematyki (Katowice: GWSH w Katowicach, 2013).

${ }^{2}$ Bernadeta Lelonek-Kuleta, „Uzależnienia behawioralne - podstawy teoretyczne”, w Uzależnienia behawioralne $i$ zachowania problemowe młodzieży, red. Jolanta Jarczyńska (Bydgoszcz: Wydawnictwo Uniwersytetu Kazimierza Wielkiego, 2014), 15-29.

3 Magdalena Rowicka, Uzależnienia behawioralne. Profilaktyka i terapia (Warszawa: Krajowe Biuro do Spraw Przeciwdziałania Narkomanii, Fundacja Praesterno, 2015).

${ }^{4}$ Andrzej Silczuk i Bogusław Habrat, „Zaburzenia uprawiania hazardu”, w Zaburzenia uprawiania hazardu i inne tak zwane nałogi behawioralne, red. Bogusław Habrat (Warszawa: Instytut Psychiatrii i Neurologii, 2016), 83-218.
} 
mimo pojawiających się szkód i negatywnych konsekwencji zarówno dla niego samego jak i jego otoczenia 5 .

$\mathrm{Z}$ doniesień medialnych i pojawiających się na rynku wydawniczym biografii sławnych osób wynika, że grupą, która ma szczególne skłonności do uprawiania hazardu, są piłkarze. Należy przy tym stwierdzić, że wyszczególniona kategoria sportowców pozostawiona jest poza szerszymi naukowymi rozważaniami, które dotyczyły opisu przedmiotowego zjawiska zarówno w perspektywie istniejącego problemu społecznego czy też zdrowia jednostki ${ }^{6}$. Niewiele również wiadomo na ile do uprawiania hazardu przyczynia się sytuacja rodzinna piłkarzy, a także ich funkcjonowanie w rodzinie, gdy byli oni dziećmi.

Celem przeprowadzonego badania $^{7}$ było rozpoznanie udziału piłkarzy z IV ligi makroregionu śląskiego w uprawianiu hazardu oraz znalezienie odpowiedzi na pytanie, czy ze względu na posiadany stan cywilny piłkarze, będący w związkach formalnych, różnią się od piłkarzy nie będących w takich związkach w sposobie podejścia do uprawiania hazardu.

\section{METODOLOGIA BADAŃ \\ I CHARAKTERYSTYKA BADANEJ GRUPY}

Badanie zostało przeprowadzone metodą sondażu diagnostycznego z wykorzystaniem autorskiej ankiety. Część merytoryczna kwestionariusza obejmowa-

\footnotetext{
${ }^{5}$ Guyonne Rogier at al., „Gambling disorder and dissociative features: A systematic review and meta-analysis”, Psychology of Addictive Behaviors 35(2021): 247-62, https://doi. org/10.1037/adb0000693; Marc N. Potenza at al., „Gambling Disorder”, Nature Reviews Disease Primers 5(2019): 51, https://doi.org/10.1038/s41572-019-0099-7; Giulio Perrotta, „Pathological gambling disorder: definition, clinical contexts and therapeutic approaches", ES Journal of Neurology 1(2020): 1004; Jeremie Richard, Thomas S. Paskus, and Jeffrey Derevensky, „Trends in gambling behavior among college student-athletes: A comparison of 2004, 2008, 2012 and 2016 NCAA survey data", Journal of Gambling Issues 41(2019): 73-100, http://dx. doi.org/10.4309/jgi.2019.41.5http://igi.camh.net/doi/pdf/10.4309/jgi.2019.41.5.

${ }^{6}$ Marie Grall-Bronnec et al., „Gambling among European professional athletes. Prevalence and associated factors”, Journal of Addictive Diseases 35(2016): 278-90, https://doi.org/10. 1080/10550887.2016.1177807; Anders Håkansson, Göran Kenttä, and Cecilia Åkesdotter, „Problem Gambling and Gaming in Elite Athletes”, Addictive Behaviors Reports 8(2018): 79-84, https://doi.org/10.1016/j.abrep.2018.08.003.

7 Prezentowane wyniki stanowią wycinek szerszego projektu: „Zaburzenia uprawiania hazardu i problemowego korzystania z internetu wśród piłkarzy". Badanie realizowała Akademia Wychowania Fizycznego im. Jerzego Kukuczki w Katowicach i było ono współfinansowane przez Krajowe Biuro ds. Przeciwdziałania Narkomanii w ramach grantu naukowego służącego pogłębianiu wiedzy w zakresie uzależnień behawioralnych, w tym hazardu problemowego i patologicznego (umowa $\mathrm{nr}$ 7/HEK/2019).
} 
ła m.in bloki pytań z zakresu zaangażowania badanych piłkarzy w hazard, ich przekonań na temat hazardu i gier hazardowych, a także powodów udziału w grze hazardowej oraz rodzinnych uwarunkowań hazardu i inicjacji do gry. Równocześnie do opracowanego narzędzia, jako jego integralną część, włączono Kanadyjski Indeks Gier Hazardowych (CPGI). Za pomocą CPGI dokonano pomiaru ryzyka uzależnienia od hazardu wśród badanych sportowców.

Wyselekcjonowana do opisu grupa liczyła 583 zawodników z 35 klubów piłkarskich IV ligi. Jako region wytypowano województwo śląskie, w którym piłka nożna jest szczególnie zakorzeniona w lokalnej społeczności, a kluby z tego województwa stanowią ważny element prowadzonych rozgrywek zarówno w aspekcie liczebnego zaangażowania jak i ich wkładu w rozwój dyscypliny. Badaniami objęto wszystkich pełnoletnich piłkarzy (całościowa populacja), którzy w sezonie 2018/2019 oraz w sezonie 2017/2018 brali udział w zawodach sportowych na poziomie piątej klasy rozgrywkowej. Wybór grupy wynikał z faktu, że wyszczególnieni sportowcy jako czwartoligowcy formalnie nie posiadają statusu zawodnika profesjonalnego. Natomiast z racji zajmowanej pozycji w hierarchii prowadzonych rozgrywek jako pierwsi w kategorii amatorów aspirują by zostać zawodowcami. Równocześnie nie obce są im pokusy, styl życia oraz wyzwania, które związane są z faktem bycia piłkarzem. Analogicznie jak u profesjonalistów towarzyszy im podobna presja, motywacja, emocje nakierowanie na współzawodnictwo oraz sposoby radzenia sobie ze stresem i występującymi problemami.

Wśród badanych zawodników najliczniej reprezentowaną kategorią wiekową byli piłkarze między 18 a 21 rokiem życia. Stanowili oni $1 / 3$ ankietowanej populacji $(31,9 \%)$. Co piąty $\mathrm{z}$ respondentów $(19,7 \%)$ legitymował się wiekiem 22-24 lata. Nieco mniej liczebna grupę (17,3\%) tworzyli piłkarze między 25 a 27 rokiem życia. Pozostały odsetek stanowili sportowcy z przedziału wiekowego 28-30 lat (16\%), 31-35 lat (9.9\%) oraz piłkarze powyżej 36 lat $(5,1 \%)$.

Respondenci to głównie mieszkańcy terenów wiejskich $(23,2 \%)$ albo miast od 100 do 150 tys. (20,6\%). Co dziesiąty z ankietowanych (11,3\%), jako miejsce swojego zamieszkania, wymieniał małe miasteczko do 20 tys. mieszkańców albo miasto mające od 20 do 50 tys. ludności (12,7\%). Prawie 17\% przebadanych wskazało, że żyje w mieście od 50 do 100 tys. a 15,4\% respondentów określiło, że jest mieszkańcem aglomeracji mających powyżej 150 tys. osób.

Co drugi ankietowany sportowiec $(55,2 \%)$, to kawaler. Co piąty piłkarz $(19,4 \%)$ przyznał, że funkcjonuje w związku nieformalnym, a 22,3\% badanych zawodników swój stan cywilny oznaczyło jako żonaty. Kilku responden- 
tów (3\%) wskazało, że jest rozwodnikiem lub aktualnie przebywa w separacji bądź jest wdowcem.

Prawie $60 \%$ sportowców zadeklarowało, że posiada wykształcenie średnie, w tym $43,7 \%$, że ma wykształcenie średnie $\mathrm{z}$ maturą. Wykształcenie wyższe pierwszego lub drugiego stopnia posiada $24,9 \%$ czwartoligowców. Do ukończenia edukacji na poziomie podstawowym lub gimnazjalnym przyznało się 6,7\% ankietowanych mężczyzn, a 9,3\% respondentów mówiąc o swoim wykształceniu określiło je jako zasadnicze zawodowe.

\section{WYNIKI PRZEPROWADZONYCH BADAŃ EMPIRYCZNYCH}

Na 583 przebadanych piłkarzy, 169 z nich $(29,0 \%)$ w ciągu ostatnich 12 miesięcy poprzedzających badanie w ogóle nie grało w gry hazardowe. Najmniej zaangażowanymi $\mathrm{w}$ grę byli żonaci piłkarze, w której to grupie co trzeci z nich nie uprawia w ogóle hazardu. Pozostały odsetek zawodników - 414 (71,0\%), przyznał się do swojego zaangażowania w grę hazardową. W grupie tej najwięcej ochoty do hazardu przejawiali zawodnicy żyjący w związkach nieformalnych $(78,8 \%)$ lub kawalerowie $(71,2 \%)^{8}$ - patrz tabela 1.

Tabela 1. Uprawianie gry hazardowej a stan cywilny badanych

\begin{tabular}{|c|c|c|c|c|c|c|c|c|c|c|}
\hline \multirow{3}{*}{$\begin{array}{l}\text { Uprawianie gry } \\
\text { hazardowej }\end{array}$} & \multicolumn{10}{|c|}{ Stan cywilny } \\
\hline & \multicolumn{2}{|c|}{ Kawaler } & \multicolumn{2}{|c|}{$\begin{array}{l}\text { W związku } \\
\text { nieformalnym }\end{array}$} & \multicolumn{2}{|c|}{ Żonaty } & \multicolumn{2}{|c|}{ Wdowiec } & \multicolumn{2}{|c|}{$\begin{array}{c}\text { Rozwodnik/ } \\
\text { separacja }\end{array}$} \\
\hline & $\mathrm{N}$ & $\%$ & $\mathrm{~N}$ & $\%$ & $\mathrm{~N}$ & $\%$ & $\mathrm{~N}$ & $\%$ & $\mathrm{~N}$ & $\%$ \\
\hline $\begin{array}{l}\text { W ogóle } \\
\text { nie gram }\end{array}$ & 93 & 28,8 & 24 & 21,2 & 46 & 35,4 & 1 & 100,0 & 5 & 29,4 \\
\hline Gram & 229 & 71,2 & 89 & 78,8 & 84 & 64,6 & 0 & 0,0 & 12 & 70,6 \\
\hline Ogółem & 322 & 100,0 & 113 & 100,0 & 130 & 100,0 & 1 & 100,0 & 17 & 100,0 \\
\hline
\end{tabular}

Źródło: Badania własne (Liczba badanych N=583)

Piłkarze, uprawiający hazard, najczęściej spośród oferowanych na rynku gier wybierali zakłady bukmacherskie o charakterze stacjonarnym lub online. $\mathrm{Z}$ tego

\footnotetext{
${ }^{8}$ Ze względu na małą liczebność poza analizą pozostawiono jednego respondenta, który wskazał, że jest wdowcem.
} 
typu formy uprawiania hazardu korzystało ogółem odpowiednio 55,0\% i 60,1\% ankietowanych sportowców. W przypadku dokonania korelacji zmiennej stanu cywilnego z obstawianiem zakładów bukmacherskich można stwierdzić, że wśród 249 respondentów - zawierających zakłady online i 228 piłkarzy wypełniających kupony w punktach stacjonarnych - w obu przypadkach prawie $60 \%$ tej grupy stanowią kawalerowie. W obstawianiu zakładów bukmacherskich równie chętnie biorą udział także piłkarze, którzy żyją w związkach nieformalnych jak i sportowcy, którzy zawarli związek małżeński. W tych kategoriach udział w obstawianiu zakładów bukmacherskich niezależnie od ich charakteru oscyluje w przedziale od 18 do 19\%. Zauważyć jednak należy, że dokonując przeliczenia liczby zawodników uprawiających bukmacherkę do liczby osób zaangażowanych w nią ze względu na zmienną stan cywilny nie występują tutaj istotnie statystyczne różnice. Tak samo w ten rodzaj hazardu uwikłani są kawalerowie jak i ankietowani, którzy żyją w związku nieformalnym czy ci, którzy są żonaci. Podkreślić wypada, że piłkarze w każdej z podkategorii stanu cywilnego częściej zawieraja zakłady bukmacherskie wykorzystując do tego internet niż czynią to w sposób tradycyjny w punktach stacjonarnych.

Oprócz zawieranych zakładów u bukmacherów, znaczny odsetek piłkarzy (50.0\%) jest zaangażowany w grę Lotto, która oferuje dla jej zwycięzców relatywnie wysokie wygrane. Również i w tym przypadku osobami najliczniej wypełniającymi kupony są kawalerowie. Co jednak charakterystyczne dla analizowanej grupy, to że gra w Lotto jest najchętniej widziana przez osoby żonate. Stanowi ona główny ich wybór spośród wszystkich gier hazardowych, w które angażują się. Gra w nią 69\% wszystkich żonatych piłkarzy, spośród tych, którzy uprawiają hazard.

Do gier, które cieszą się względnym uznaniem wśród piłkarzy, zaliczyć wypada także kupowanie przez nich zdrapek. Z tej formy hazardu korzysta 181 spośód wszystkich grających sportowców $(43,7 \%)$.

Poza wyżej wymienionymi grami oraz udziałem w konkursach SMS-owych $(17,6 \%)$, badani piłkarze stosunkowo rzadko korzystają z innego rodzaju hazardu. Można powiedzieć, że incydentalnie próbują swoich sił w grach na automatach, czy też w innych rodzajach hazardu. Szczegółowy rozkład odpowiedzi w zakresie udziału badanych w grach hazardowych przedstawia tabela 2 .

Obok uzyskania odpowiedzi ilu piłkarzy uprawia hazard i z których gier najczęściej oni korzystają, kolejną kwestią było ustalenie z jaką robią to częstotliwością. W celu zbadania wskazanego wątku poproszono respondentów o określenie stopnia intensywności ich udziału w grze hazardowej. 
Tabela 2. Uczestniczenie w grach hazardowych przez piłkarzy deklarujących udział w hazardzie

\begin{tabular}{|c|c|c|c|c|c|c|c|c|c|c|}
\hline \multirow{3}{*}{ Rodzaj gry } & \multicolumn{8}{|c|}{ Stan cywilny } & \multirow{2}{*}{\multicolumn{2}{|c|}{ Ogółem }} \\
\hline & \multicolumn{2}{|c|}{ Kawaler } & \multicolumn{2}{|c|}{$\begin{array}{l}\text { W związku } \\
\text { nieformalnym }\end{array}$} & \multicolumn{2}{|c|}{ Żonaty } & \multicolumn{2}{|c|}{$\begin{array}{l}\text { Rozwodnik/ } \\
\text { Separacja }\end{array}$} & & \\
\hline & $\mathrm{N}$ & $\%$ & $\mathrm{~N}$ & $\%$ & $\mathrm{~N}$ & $\%$ & $\mathrm{~N}$ & $\%$ & $\mathrm{~N}$ & $\%$ \\
\hline Lotto & 100 & 48,3 & 40 & 19,4 & 58 & 28,0 & 9 & 4,3 & 207 & 100,0 \\
\hline $\begin{array}{l}\text { Keno oraz inne } \\
\text { gry losowe }\end{array}$ & 56 & 54,9 & 22 & 21,6 & 18 & 17,6 & 6 & 5,9 & 102 & 100,0 \\
\hline Zdrapki & 104 & 57,5 & 38 & 21,0 & 32 & 17,6 & 7 & 3,9 & 181 & 100,0 \\
\hline $\begin{array}{l}\text { Konkursy SMS- } \\
\text { owe }\end{array}$ & 39 & 53,4 & 13 & 17,8 & 17 & 23,3 & 4 & 5,5 & 73 & 100,0 \\
\hline $\begin{array}{l}\text { Bukmacherka } \\
\text { stacjonarna }\end{array}$ & 135 & 59,2 & 43 & 18,9 & 42 & 18,4 & 8 & 3,5 & 228 & 100,0 \\
\hline $\begin{array}{l}\text { Bukmacherka } \\
\text { online }\end{array}$ & 149 & 59,8 & 47 & 18,9 & 45 & 18,1 & 8 & 3,2 & 249 & 100,0 \\
\hline $\begin{array}{l}\text { Automaty do } \\
\text { gier }\end{array}$ & 27 & 44,3 & 12 & 19,7 & 16 & 26,2 & 6 & 9,8 & 61 & 100,0 \\
\hline Loterie pieniężne & 12 & 54,5 & 5 & 22,7 & 4 & 18,2 & 1 & 4,6 & 22 & 100,0 \\
\hline Loterie fantowe & 8 & 53,3 & 4 & 26,7 & 2 & 13,3 & 1 & 6,7 & 15 & 100,0 \\
\hline $\begin{array}{l}\text { Bingo pieniężne } \\
\text { lub fantowe }\end{array}$ & 13 & 56,6 & 7 & 30,4 & 1 & 4,3 & 2 & 8,7 & 23 & 100,0 \\
\hline $\begin{array}{l}\text { Karty, kości, } \\
\text { ruletka }\end{array}$ & 18 & 52,9 & 7 & 20,6 & 6 & 17,7 & 3 & 8,8 & 34 & 100,0 \\
\hline $\begin{array}{l}\text { Inna gra hazar- } \\
\text { dowa }\end{array}$ & 10 & 55,6 & 4 & 22,2 & 3 & 16,7 & 1 & 5,5 & 18 & 100,0 \\
\hline Ogółem & 229 & 55,3 & 89 & 21,5 & 84 & 20,2 & 13 & 3,0 & 414 & 100,0 \\
\hline
\end{tabular}

Źródło: Badania własne (Liczba badanych N=414)

Co dziesiąty z piłkarzy $(11,1 \%)$ uprawiający hazard wskazał, że robi to systematycznie. Tak samo liczna grupa zawodników (11.4\%) nie potrafiła precyzyjnie określić swojego zaangażowania w tym obszarze. Prawie $30 \%$ ze sportowców stwierdziło, że robi to okazjonalnie, a blisko połowa respondentów $(47,8 \%)$ zadeklarowała, że ma to charakter nieregularny - od czasu do czasu. Z taką częstotliwością grają głównie żonaci piłkarze $(57,2 \%)$. W tej kategorii ankietowanych mężczyzn odnotowano również najmniejszy odsetek osób, które mówiły o swojej systematycznej grze $(8,3 \%)$. W pozostałych podkategoriach ułamek ten jest o parę punktów procentowych większy i wyniósł od 11 do 16\%. Szczegółowy rozkład odpowiedzi prezentuje tabela 3 . 
Tabela 3. Częstotliwość uprawiania gier hazardowych a stan cywilny badanych

\begin{tabular}{|l|c|c|c|c|c|c|c|c|c|c|}
\hline \multirow{3}{*}{ Częstotliwość gry } & \multicolumn{8}{|c|}{ Kawaler } & \multicolumn{1}{|c|}{$\begin{array}{c}\text { W związku } \\
\text { nieformalnym }\end{array}$} & \multicolumn{2}{|c|}{ Żonaty } & \multicolumn{2}{c|}{$\begin{array}{c}\text { Rozwodnik/ } \\
\text { separacja }\end{array}$} & \multicolumn{2}{c|}{ Ogółem } \\
\cline { 2 - 15 } & $\mathrm{N}$ & & $\mathrm{N}$ & $\%$ & $\mathrm{~N}$ & $\%$ & $\mathrm{~N}$ & $\%$ & $\mathrm{~N}$ & $\%$ \\
\cline { 2 - 15 } & 27 & 11,8 & 10 & 11,2 & 7 & 8,3 & 2 & 16,7 & 46 & 11,1 \\
\hline Systematycznie & 68 & 29,7 & 29 & 32,6 & 22 & 26,2 & 4 & 33,3 & 123 & 29,7 \\
\hline Okazjonalnie & 106 & 46,3 & 39 & 43,8 & 48 & 57,2 & 5 & 41,7 & 198 & 47,8 \\
\hline $\begin{array}{l}\text { Od czasu do } \\
\text { czasu }\end{array}$ & 28 & 12,2 & 11 & 12,4 & 7 & 8,3 & 1 & 8,3 & 47 & 11,4 \\
\hline $\begin{array}{l}\text { Trudno powie- } \\
\text { dzieć }\end{array}$ & 229 & 100,0 & 89 & 100,0 & 84 & 100,0 & 12 & 100,0 & 414 & 100,0 \\
\hline Ogółem & & & & & & & & & \\
\hline
\end{tabular}

Źródło: Badania własne (Liczba badanych N=414)

Na podstawie otrzymanych wyników można powiedzieć, że piłkarze w dokonanym samoopisie wskazali, iż ich udział w grze hazardowej ma raczej charakter rekreacyjny. Próbę potwierdzenia prawdziwości tego wniosku postanowiono skonfrontować dokonując analizy otrzymanych informacji na podstawie kwestionariusza CPGI.

Jeśli chodzi o poziom uzależnienia od hazardu, mierzony Kanadyjskim Indeksem Gier Hazardowych (CPGI), z klinicznego punktu widzenia można rozpatrywać je na kontinuum od braku zaangażowania $\mathrm{w}$ grę do stadium występującej w tym zakresie patologii.

Analizując otrzymane wyniki ustalono, że aktywność hazardowa wśród piłkarzy jest zróżnicowana. Nie wszyscy z nich grają tak samo intensywnie i nie wszystkim towarzyszą podobne problemy. W grupie uprawiających hazard znajduje się ponad połowa piłkarzy, którzy grają rekreacyjnie i z tego tytułu nie występują u nich żadne dysfunkcje związane z hazardem. Największy odsetek osób w tej kategorii stanowią żonaci sportowcy (56.0\%). Także znaczny odsetek niewykazujących problemów z grą dotyczy zawodników z każdej kolejnej grupy dla zmiennej stan cywilny. Jednak w grupach tych procent osób bez oznak problemów z uprawianiem hazardu obejmuje mniej niż $1 / 2$ zawodników.

Pierwsze (incydentalne) symptomy zachwiania kontroli nad swoją gra hazardową wykazuje $22,9 \%$ badanej populacji graczy. W grupie tej co czwarty piłkarz jest kawalerem $(25,8 \%)$ a co piąty $(21,4 \%)$ ma żonę. Natomiast umiarkowany poziom ryzyka uzależnienia się od hazardu zaobserwowano 
u co siódmego z grających sportowców (14,3\%). Przy czym największe nasilenie tego zagrożenia dotyczy piłkarzy rozwodników lub będących w separacji (25\%) oraz piłkarzy żyjących w konkubinacie $(18,0 \%)$.

$\mathrm{Z}$ uzyskanych informacji wynika, że problem $\mathrm{z}$ hazardem występuje u $12,6 \%$ piłkarzy uprawiających tego typu rozrywkę. Podobnie jak miało to miejsce na poziomie umiarkowanego ryzyka uzależnienia się od hazardu, występujące zaburzenie w największym stopniu dotyka przede wszystkim rozwodników i osób będących w separacji oraz piłkarzy funkcjonujących w związkach nieformalnych. Szczegółowy rozkład zmiennej poziomu ryzyka uzależnienia się od hazardu przedstawia tabela 4.

Tabela 4. Poziom ryzyka uzależnienia od hazardu badanych piłkarzy według CPGI a stan cywilny respondentów

\begin{tabular}{|c|c|c|c|c|c|c|c|c|c|c|}
\hline \multirow{3}{*}{$\begin{array}{c}\text { Wynik testu } \\
\text { CPGI }\end{array}$} & \multicolumn{10}{|c|}{ Stan cywilny } \\
\hline & \multicolumn{2}{|c|}{ Kawaler } & \multicolumn{2}{|c|}{$\begin{array}{l}\text { W związku } \\
\text { nieformalnym }\end{array}$} & \multicolumn{2}{|c|}{ Żonaty } & \multicolumn{2}{|c|}{$\begin{array}{l}\text { Rozwodnik/ } \\
\text { separacja }\end{array}$} & \multicolumn{2}{|c|}{ Ogółem } \\
\hline & $\mathrm{N}$ & $\%$ & $\mathrm{~N}$ & $\%$ & $\mathrm{~N}$ & $\%$ & $\mathrm{~N}$ & $\%$ & $\mathrm{~N}$ & $\%$ \\
\hline $\begin{array}{l}\text { Brak proble- } \\
\text { mów }\end{array}$ & 114 & 49,8 & 42 & 47,2 & 47 & 56,0 & 5 & 41,7 & 208 & 50,2 \\
\hline $\begin{array}{l}\text { Niski poziom } \\
\text { ryzyka }\end{array}$ & 59 & 25,8 & 17 & 19,1 & 18 & 21,4 & 1 & 8,3 & 95 & 22,9 \\
\hline $\begin{array}{l}\text { Umiarkowany } \\
\text { poziom ryzyka }\end{array}$ & 29 & 12,7 & 16 & 18,0 & 11 & 13,1 & 3 & 25,0 & 59 & 14,3 \\
\hline $\begin{array}{l}\text { Problem z ha- } \\
\text { zardem }\end{array}$ & 27 & 11,7 & 14 & 15,7 & 8 & 9,5 & 3 & 25,0 & 52 & 12,6 \\
\hline Ogółem & 229 & 100,0 & 89 & 100,0 & 84 & 100,0 & 12 & 100,0 & 414 & 100,0 \\
\hline
\end{tabular}

Źródło: Badania własne (Liczba badanych N=414)

Rozpoznając zagadnienie uprawiania hazardu przez piłkarzy piątego szczebla rozgrywek sprawdzono jakie towarzyszą im przekonania na temat hazardu. Dotychczasowe badania konsekwentnie dostarczają bowiem dowodów, które łączą nałogowy hazard (problemowy/patologiczny) z błędnymi przekonaniami na temat hazardu, a także informują, że błędne przekonania o hazardzie zwiększają prawdopodobieństwo angażowania się $\mathrm{w}$ grę i stanowią istotny czynnik ryzyka problemowego grania ${ }^{9}$.

\footnotetext{
${ }^{9}$ Iwona Niewiadomska i in., Bateria metod stużacych do oceny ryzyka zaburzeń zwiazanych z hazardem (Lublin: Instytut Psychoprofilaktyki i Psychoterapii, Stowarzyszenie Natanaelum, 2014).
} 
Pierwszą z poruszonych kwestii było to czy zdaniem piłkarzy uprawianie hazardu przysparza życiowych problemów. Zdecydowanie o istnieniu takiego związku przyczynowo-skutkowego było przekonanych $21,6 \%$ piłkarzy. Równocześnie co drugi ze sportowców $(50,8 \%)$ uznał przytoczone stwierdzenie za prawdziwe lub raczej prawdziwe. Przeciwne stanowisko co do słuszności stwierdzenia wyraziło $27,6 \%$ ankietowanych zawodników, którzy w swojej odpowiedzi zaznaczyli, że jest to zdecydowanie nieprawda $(11,8 \%)$ lub nieprawda $(15,8 \%)$. O braku występowania życiowych problemów, które stanowiłyby następstwo uprawiania hazardu wypowiadali się przede wszystkim piłkarze będący kawalerami bądź funkcjonujący w związkach nieformalnych. Natomiast kategorią osób, która dostrzegała w hazardzie możliwość wystąpienia życiowych problemów, byli głównie żonaci sportowcy $(33,1 \%)$ lub zawodnicy po rozpadzie swojego związku małżeńskiego (35.3\%). Równocześnie w grupach tych odnotowano także największy odsetek respondentów, którzy mniej lub bardziej kategorycznie, ale opowiadali się za prawdziwością zawartej tezy w postawionym im pytaniu. Szczegółowy rozkład odpowiedzi ukazuje tabela 5 .

Tabela 5. Opinia badanych na temat występowania życiowych problemów w następstwie uprawiania hazardu a stan cywilny piłkarzy

\begin{tabular}{|c|c|c|c|c|c|c|c|c|c|c|c|c|}
\hline \multirow{3}{*}{$\begin{array}{l}\text { Uprawianie } \\
\text { hazardu } \\
\text { przysparza } \\
\text { życiowych } \\
\text { problemów }\end{array}$} & \multicolumn{12}{|c|}{ Stan cywilny } \\
\hline & \multicolumn{2}{|c|}{ Kawaler } & \multicolumn{2}{|c|}{$\begin{array}{l}\text { W związku } \\
\text { nieformalnym }\end{array}$} & \multicolumn{2}{|c|}{ Żonaty } & \multicolumn{2}{|c|}{ Wdowiec } & \multicolumn{2}{|c|}{$\begin{array}{c}\text { Rozwodnik/ } \\
\text { separacja }\end{array}$} & \multicolumn{2}{|c|}{ Ogółem } \\
\hline & $\mathrm{N}$ & $\%$ & $\mathrm{~N}$ & $\%$ & $\mathrm{~N}$ & $\%$ & $\mathrm{~N}$ & $\%$ & $\mathrm{~N}$ & $\%$ & $\mathrm{~N}$ & $\%$ \\
\hline $\begin{array}{l}\text { Zdecydowanie } \\
\text { nieprawda }\end{array}$ & 43 & 13,4 & 12 & 10,6 & 12 & 9,2 & 1 & 100 & 1 & 5,9 & 69 & 11,8 \\
\hline Nieprawda & 57 & 17,7 & 23 & 20,4 & 11 & 8,5 & 0 & 0,0 & 1 & 5,9 & 92 & 15,8 \\
\hline Raczej prawda & 81 & 25,2 & 28 & 24,8 & 23 & 17,7 & 0 & 0,0 & 5 & 29,4 & 137 & 23,5 \\
\hline Prawda & 83 & 25,7 & 31 & 27,4 & 41 & 31,5 & 0 & 0,0 & 4 & 23,5 & 159 & 27,3 \\
\hline $\begin{array}{l}\text { Zdecydowanie } \\
\text { prawda }\end{array}$ & 58 & 18,0 & 19 & 16,8 & 43 & 33,1 & 0 & 0,0 & 6 & 35,3 & 126 & 21,6 \\
\hline Ogółem & 322 & 100,0 & 113 & 100,0 & 130 & 100,0 & 1 & 100,0 & 17 & 100,0 & 583 & 100,0 \\
\hline
\end{tabular}

Źródło: Badania własne (Liczba badanych N=583)

Kolejnym sprawdzanym zagadnieniem było to czy badani uważają, iż każda gra hazardowa może prowadzić do uzależnienia. 
Tabela 6. Opinia badanych na temat możliwości uzależnienia się od hazardu a stan cywilny piłkarzy

\begin{tabular}{|c|c|c|c|c|c|c|c|c|c|c|c|c|}
\hline \multirow{3}{*}{$\begin{array}{l}\text { Każda gra } \\
\text { hazardowa } \\
\text { może } \\
\text { uzależnić }\end{array}$} & \multicolumn{12}{|c|}{ Stan cywilny } \\
\hline & \multicolumn{2}{|c|}{ Kawaler } & \multicolumn{2}{|c|}{$\begin{array}{c}\text { W związku } \\
\text { nieformalnym }\end{array}$} & \multicolumn{2}{|c|}{ Żonaty } & \multicolumn{2}{|c|}{ Wdowiec } & \multicolumn{2}{|c|}{$\begin{array}{c}\text { Rozwodnik/ } \\
\text { separacja }\end{array}$} & \multicolumn{2}{|c|}{ Ogółem } \\
\hline & $\mathrm{N}$ & $\%$ & $\mathrm{~N}$ & $\%$ & $\mathrm{~N}$ & $\%$ & $\mathrm{~N}$ & $\%$ & $\mathrm{~N}$ & $\%$ & $\mathrm{~N}$ & $\%$ \\
\hline $\begin{array}{l}\text { Zdecydowanie } \\
\text { nieprawda }\end{array}$ & 26 & 8,1 & 6 & 5,3 & 16 & 12,3 & 0 & 0,0 & 2 & 11,8 & 50 & 8,6 \\
\hline Nieprawda & 28 & 8,7 & 11 & 9,7 & 9 & 6,9 & 1 & 100 & 2 & 11,8 & 51 & 8,7 \\
\hline $\begin{array}{l}\text { Raczej } \\
\text { prawda }\end{array}$ & 61 & 18,9 & 23 & 20,4 & 29 & 22,3 & 0 & 0,0 & 5 & 29,4 & 118 & 20,2 \\
\hline Prawda & 84 & 26,1 & 33 & 29,2 & 31 & 23,8 & 0 & 0,0 & 5 & 29,4 & 153 & 26,3 \\
\hline $\begin{array}{l}\text { Zdecydowanie } \\
\text { prawda }\end{array}$ & 123 & 38,2 & 40 & 35,4 & 45 & 34,7 & 0 & 0,0 & 3 & 17,6 & 211 & 36,2 \\
\hline Ogółem & 322 & 100,0 & 113 & 100,0 & 130 & 100,0 & 1 & 100,0 & 17 & 100,0 & 583 & 100,0 \\
\hline
\end{tabular}

Źródło: Badania własne (Liczba badanych $\mathrm{N}=583$ )

$\mathrm{Z}$ analizy uzyskanych wypowiedzi wynika, że istnieje podgrupa piłkarzy (17,3\%), którzy uważają, że nie każda gra hazardowa prowadzi bezpośrednio do nałogowego (patologicznego) grania. W grupie tej, obejmującej 101 sportowców, jej trzon stanowiło 54 piłkarzy kawalerów oraz 25 żonatych zawodników. Pozostały odsetek respondentów mniej lub bardziej zdecydowanie twierdził, że nie istnieją bezpieczne gry hazardowe i niezależnie z jakich form hazardu korzystamy, może on doprowadzić nas do uzależnienia się od niego. Szczegółowy rozkład odpowiedzi patrz tabela 6 .

Weryfikując przekonania piłkarzy na temat hazardu, sprawdzono przy tym czy w ich opinii są rodzaje gier, od których można się łatwiej uzależnić. W skonstruowanej na tę okoliczność dziesięciostopniowej skali określono, że wystawiona ocena „1” oznacza, że „ta gra w ogóle nie uzależnia, a „10” oznacza, że „ta gra uzależnia w bardzo dużym stopniu”.

Za najbardziej niebezpieczne (uzależniające) gry hazardowe piłkarze uznali: zakłady bukmacherskie w internecie $\left(x^{-}=7,88, M e=8,00, D o=10\right)$, zakłady bukmacherskie poza internetem $\left(x^{-}=6,72, M e=7,00, D o=10\right)$ oraz gry na automatach w sieci $\left(x^{-}=6.34, M e=7.00, D o=10\right)$. Natomiast do gier hazardowych, które najmniej uzależniają zaliczyli: zdrapki $\left(x^{-}=4,68, M e=5,00\right.$, $D o=5)$, loterie i konkursy SMS-owe $\left(x^{-}=4,20, M e=4,00, D o=1\right)$ oraz gry liczbowe $\left(x^{-}=5,13, M e=5\right)$. 
Tabela 7. Przekonanie badanych na temat szkodliwości hazardu a stan cywilny piłkarzy

\begin{tabular}{|c|c|c|c|c|c|c|c|c|c|c|c|c|}
\hline \multirow{3}{*}{$\begin{array}{l}\text { Hazard to } \\
\text { nieszkodliwa } \\
\text { rozrywka }\end{array}$} & \multicolumn{12}{|c|}{ Stan cywilny } \\
\hline & \multicolumn{2}{|c|}{ Kawaler } & \multicolumn{2}{|c|}{$\begin{array}{c}\mathrm{W} \text { związku } \\
\text { nieformalnym }\end{array}$} & \multicolumn{2}{|c|}{ Żonaty } & \multicolumn{2}{|c|}{ Wdowiec } & \multicolumn{2}{|c|}{$\begin{array}{c}\text { Rozwodnik/ } \\
\text { separacja }\end{array}$} & \multicolumn{2}{|c|}{ Ogółem } \\
\hline & $\mathrm{N}$ & $\%$ & $\mathrm{~N}$ & $\%$ & $\mathrm{~N}$ & $\%$ & $\mathrm{~N}$ & $\%$ & $\mathrm{~N}$ & $\%$ & $\mathrm{~N}$ & $\%$ \\
\hline $\begin{array}{l}\text { Zdecydowanie } \\
\text { nieprawda }\end{array}$ & 106 & 32,9 & 33 & 29,2 & 60 & 46,2 & 0 & 0,0 & 5 & 29,4 & 204 & 35,0 \\
\hline Nieprawda & 120 & 37,3 & 51 & 45,1 & 44 & 33,8 & 1 & 100 & 3 & 17,6 & 219 & 37,6 \\
\hline Raczej prawda & 57 & 17,7 & 14 & 12,4 & 18 & 13,8 & 0 & 0,0 & 7 & 41,2 & 96 & 16,4 \\
\hline Prawda & 25 & 7,8 & 12 & 10,6 & 6 & 4,7 & 0 & 0,0 & 1 & 5,9 & 44 & 7,5 \\
\hline $\begin{array}{l}\text { Zdecydowanie } \\
\text { prawda }\end{array}$ & 14 & 4,3 & 3 & 2,7 & 2 & 1,5 & 0 & 0,0 & 1 & 5,9 & 20 & 3,5 \\
\hline Ogółem & 322 & 100,0 & 113 & 100,0 & $130 \mid$ & 100,0 & 1 & 100,0 & 17 & 100,0 & 583 & 100,0 \\
\hline
\end{tabular}

Źródło: Badania własne (Liczba badanych N=583)

Swoją opinię o istniejącym zagrożeniu ze strony gier hazardowych ankietowani sportowcy podtrzymali udzielając odpowiedzi na pytanie: Czy hazard można uznać za nieszkodliwą rozrywkę? Ponad $70 \%$ piłkarzy było zdania, że jest to zdecydowanie nieprawda $(35,0 \%)$ lub nieprawda $(37,6 \%)$. Za takim stanowiskiem opowiadali się przede wszystkim żonaci zawodnicy oraz sportowcy pozostający w nieformalnych związkach. Szczegółowy rozkład odpowiedzi ukazuje tabela 7.

W sposób bardziej stonowany i mniej kategoryczny wypowiedzieli się natomiast badani na okoliczność postawienia ewentualnego znaku równości między uprawianiem hazardu a zostaniem przez to bankrutem. Zdecydowanie taką istniejącą zależność widzi co dziesiąty z piłkarzy $(12,7 \%)$, a co piąty $(20,8 \%)$ uznaje ją za prawdopodobną. Ponadto na skutek uprawiania hazardu $26,4 \%$ ankietowanych osób dostrzega pewne prawdopodobieństwo wystąpienia załamania finansowego prowadzącego bezpośrednio do upadłości. Takiego zagrożenia w ogóle nie dostrzega 13,4\% piłkarzy spośród wszystkich kawalerów oraz $10,7 \%$ sportowców z grupy żonatych osób. Natomiast 37,2\% osób żyjących w konkubinacie uznaje to za mało prawdopodobne, ale potencjalnie możliwe do zaistnienia. Analogiczny pogląd w tym zakresie wyraża $28,3 \%$ kawalerów i $22,3 \%$ żonatych mężczyzn. Szczegółowy rozkład odpowiedzi patrz tabela 8 . 
Tabela 8. Przekonanie badanych o możliwości stania się bankrutem w następstwie uprawiania hazardu a stan cywilny piłkarzy

\begin{tabular}{|c|c|c|c|c|c|c|c|c|c|c|c|c|}
\hline \multirow{3}{*}{$\begin{array}{c}\text { Każdy } \\
\text { hazardzista to } \\
\text { potencjalny } \\
\text { bankrut }\end{array}$} & \multicolumn{12}{|c|}{ Stan cywilny } \\
\hline & \multicolumn{2}{|c|}{ Kawaler } & \multicolumn{2}{|c|}{\begin{tabular}{|c|} 
W związku \\
nieformalnym
\end{tabular}} & \multicolumn{2}{|c|}{ Żonaty } & \multicolumn{2}{|c|}{ Wdowiec } & \multicolumn{2}{|c|}{$\begin{array}{l}\text { Rozwodnik/ } \\
\text { separacja }\end{array}$} & \multicolumn{2}{|c|}{ Ogółem } \\
\hline & $\mathrm{N}$ & $\%$ & $\mathrm{~N}$ & $\%$ & $\mathrm{~N}$ & $\%$ & $\mathrm{~N}$ & $\%$ & $\mathrm{~N}$ & $\%$ & $\mathrm{~N}$ & $\%$ \\
\hline $\begin{array}{l}\text { Zdecydowanie } \\
\text { nieprawda }\end{array}$ & 43 & 13,4 & 11 & 9,7 & 14 & 10,7 & 0 & 0,0 & 1 & 5,9 & 69 & 11,8 \\
\hline Nieprawda & 91 & 28,3 & 42 & 37,2 & 29 & 22,3 & 1 & 100 & 2 & 11,8 & 165 & 28,3 \\
\hline Raczej prawda & 81 & 25,2 & 29 & 25,7 & 37 & 28,5 & 0 & 0,0 & 7 & 41,2 & 154 & 26,4 \\
\hline Prawda & 69 & 21,4 & 22 & 19,5 & 26 & 20,0 & 0 & 0,0 & 4 & 23,5 & 121 & 20,8 \\
\hline $\begin{array}{l}\text { Zdecydowanie } \\
\text { prawda }\end{array}$ & 38 & 11,7 & 9 & 7,9 & 24 & 18,5 & 0 & 0,0 & 3 & 17,6 & 74 & 12,7 \\
\hline Ogółem & 322 & 100,0 & 113 & 100,0 & 130 & 100,0 & 1 & 100,0 & 17 & 100,0 & 583 & 100,0 \\
\hline
\end{tabular}

Źródło: Badania własne (Liczba badanych N=583)

Brak stanowczych opinii na temat możliwości zostania bankrutem na skutek uprawiania hazardu wynikać mógł z faktu, że badani piłkarze, mówiąc o wydatkowanych w ciagu roku przez siebie kwotach na grę, w zdecydowanej większości wskazywali na jej niski próg. Dla $29 \%$ z graczy nakłady ponoszone na hazard w ciągu ostatnich 12 miesięcy poprzedzających udział w badaniu wynosiły do 100 zł., a dla kolejnych 38\% ankietowanych obejmowały nakłady od 100 do 1000 zł. Roczne kwoty na hazard od 100 do 1000 zł. równie chętnie przeznaczali żonaci sportowcy, jak i ci, którzy funkcjonowali w związku nieformalnym. Z podobną intensywnością robili to również piłkarze będący stanu wolnego bądź pozostający w separacji lub po rozwodzie. Ci ostatni, w odniesieniu do innych wyselekcjonowanych badawczo grup chętniej angażują w przeciągu roku większe środki na hazard (od 1000 do $5000 \mathrm{zł.),}$ ale pozostaje to bez istotnej statystycznie zależności.

Wielkość ponoszonych nakładów na grę sugeruje, że znaczny odsetek badanej populacji piłkarzy doskonale zdaje sobie sprawę, że natura hazardu wiąże się z tym, iż gracze często przegrywają swoje pieniądze, a hazard nierozerwalnie wiąże się z ryzykiem ${ }^{10}$.

Ankietowani zawodnicy uważają również, że nie istnieje bezpośredni związek pomiędzy osobistym odczuwaniem szczęścia a uprawianiem hazardu

\footnotetext{
${ }^{10}$ Emilia Rutkowska i Bernadeta Lelonek-Kuleta, ,Robert Ladouceur's cognitive-behavioural conception of therapy for pathological gamblers", Psychoterapia 2(2018): 47-62.
} 
$(78,4 \%)$. Pogląd ten w takim samym stopniu i nasileniu podzielają zawodnicy niezależnie od tego jaką kategorię osób reprezentują ze względu na swój stan cywilny. Szczegółowy rozkład odpowiedzi patrz tabela 9.

Tabela 9. Przekonanie badanych o odczuwanym szczęściu w związku z uprawianym hazardem a stan cywilny piłkarzy

\begin{tabular}{|c|c|c|c|c|c|c|c|c|c|c|c|c|}
\hline \multirow{3}{*}{$\begin{array}{l}\text { Systematycznie } \\
\text { grający są } \\
\text { bardziej } \\
\text { szczęśliwi od } \\
\text { nie grających }\end{array}$} & \multicolumn{12}{|c|}{ Stan cywilny } \\
\hline & \multicolumn{2}{|c|}{ Kawaler } & \multicolumn{2}{|c|}{$\begin{array}{c}\text { W związku } \\
\text { nieformalnym }\end{array}$} & \multicolumn{2}{|c|}{ Żonaty } & \multicolumn{2}{|c|}{ Wdowiec } & \multicolumn{2}{|c|}{$\begin{array}{l}\text { Rozwodnik/ } \\
\text { separacja }\end{array}$} & \multicolumn{2}{|c|}{ Ogółem } \\
\hline & $\mathrm{N}$ & $\%$ & $\mathrm{~N}$ & $\%$ & $\mathrm{~N}$ & $\%$ & $\mathrm{~N}$ & $\%$ & $\mathrm{~N}$ & $\%$ & $\mathrm{~N}$ & $\%$ \\
\hline $\begin{array}{l}\text { Zdecydowanie } \\
\text { nieprawda }\end{array}$ & 110 & 34,2 & 47 & 41,6 & 60 & 46,2 & 0 & 0,0 & 5 & 29,4 & 222 & 38,1 \\
\hline Nieprawda & 149 & 46,3 & 38 & 33,6 & 43 & 33,1 & 1 & 100 & 4 & 23,5 & 235 & 40,3 \\
\hline Raczej prawda & 40 & 12,4 & 16 & 14,2 & 17 & 13,1 & 0 & 0,0 & 5 & 29,4 & 78 & 13,4 \\
\hline Prawda & 16 & 4,9 & 10 & 8,8 & 7 & 5,3 & 0 & 0,0 & 2 & 11,8 & 35 & 6,0 \\
\hline $\begin{array}{l}\text { Zdecydowanie } \\
\text { prawda }\end{array}$ & 7 & 2,2 & 2 & 1,8 & 3 & 2,3 & 0 & 0,0 & 1 & 5,9 & 13 & 2,2 \\
\hline Ogółem & 322 & 100,0 & 113 & 100,0 & 130 & 100,0 & 1 & 100,0 & 17 & 100,0 & 583 & 100,0 \\
\hline
\end{tabular}

Źródło: Badania własne (Liczba badanych N=583)

Z przeprowadzonej analizy wynika, że pewien odsetek badanych piłkarzy $(19,9 \%)$ neguje fakt przypadkowości rządzący rezultatem gry hazardowej. W opinii członków tej grupy bez względu na rodzaj gry są strategie, które pomagają wygrywać. Taki sposób bezwarunkowego myślenia o braku czynnika losowości gry podziela $5,5 \%$ biorących udział w badaniu sportowców. Jednocześnie co dziesiąty respondent $(14,4 \%)$, choć ma podobne zdanie na ten temat, tym niemniej jego wypowiedzi towarzyszy nieco mniej zdecydowania. Dodatkowo 31,7\% piłkarzy przychyla się do takiego ujęcia sprawy, uznając za raczej prawdziwe tego typu stwierdzenie.

Zdaniem Bernadety Lelonek-Kulety istnieja różne sposoby wyjaśnienia negowania faktu przypadku rządzącego wynikiem gry hazardowej. Częstym źródłem takiej negacji jest choćby nadmierna wiara gracza w posiadane przez siebie kompetencje i wiedzę ${ }^{11}$. Tak czy inaczej na 583 ankietowane osoby,

\footnotetext{
${ }^{11}$ Bernadeta Lelonek-Kuleta, „Wiara w szczęśliwy los drogą do cierpienia? Patologiczny hazard w podejściu poznawczym", Horyzonty Psychologii 3(2013): 107-24.
} 
116 z nich i kolejnych 185 błędnie uznaje, że można wpływać na grę nie tylko licząc na element szczęścia i uśmiech losu. Co warte podkreślenia jednostkami, które wykazały największą racjonalność w tym względzie, byli żonaci piłkarze. Osoby, reprezentujące tę kategorię, przy uwzględnieniu zmiennej stan cywilny, statystycznie najczęściej spośród pozostałych grup odrzucali tezę o istnieniu strategii pozwalających wygrać. Szczegółowy rozkład odpowiedzi patrz tabela 10.

Tabela 10. Opinia badanych na temat istnienia strategii, które pozwalają wygrać a stan cywilny piłkarzy

\begin{tabular}{|c|c|c|c|c|c|c|c|c|c|c|c|c|}
\hline \multirow{3}{*}{$\begin{array}{l}\text { Bez względu } \\
\text { na rodzaj gry, } \\
\text { istnieją } \\
\text { strategie, } \\
\text { które poma- } \\
\text { gają wygrać }\end{array}$} & \multicolumn{12}{|c|}{ Stan cywilny } \\
\hline & \multicolumn{2}{|c|}{ Kawaler } & \multicolumn{2}{|c|}{$\begin{array}{l}\text { W związku } \\
\text { nieformalnym }\end{array}$} & \multicolumn{2}{|c|}{ Żonaty } & \multicolumn{2}{|c|}{ Wdowiec } & \multicolumn{2}{|c|}{$\begin{array}{c}\text { Rozwodnik/ } \\
\text { separacja }\end{array}$} & \multicolumn{2}{|c|}{ Ogółem } \\
\hline & $\mathrm{N}$ & $\%$ & $\mathrm{~N}$ & $\%$ & $\mathrm{~N}$ & $\%$ & $\mathrm{~N}$ & $\%$ & $\mathrm{~N}$ & $\%$ & $\mathrm{~N}$ & $\%$ \\
\hline $\begin{array}{l}\text { Zdecydowani } \\
\text { e nieprawda }\end{array}$ & 47 & 14,6 & 13 & 11,5 & 35 & 26,9 & 0 & 0,0 & 5 & 29,4 & 100 & 17,2 \\
\hline Nieprawda & 92 & 28,6 & 36 & 31,9 & 49 & 37,7 & 1 & 100,0 & 4 & 23,5 & 182 & 31,2 \\
\hline $\begin{array}{l}\text { Raczej } \\
\text { prawda }\end{array}$ & 119 & 36,9 & 37 & 32,7 & 23 & 17,7 & 0 & 0,0 & 6 & 35,3 & 185 & 31,7 \\
\hline Prawda & 47 & 14,6 & 19 & 16,8 & 17 & 13,1 & 0 & 0,0 & 1 & 5,9 & 84 & 14,4 \\
\hline $\begin{array}{l}\text { Zdecydowani } \\
\text { e prawda }\end{array}$ & 17 & 5,3 & 8 & 7,1 & 6 & 4,6 & 0 & 0,0 & 1 & 5,9 & 32 & 5,5 \\
\hline Ogółem & 322 & 100,0 & 113 & 100,0 & 130 & 100,0 & 1 & 100,0 & 17 & 100,0 & 583 & 100,0 \\
\hline
\end{tabular}

Źródło: Badania własne (Liczba badanych N=583)

Rodzina była, jest i pozostanie najistotniejszym środowiskiem dla rozwoju każdego człowieka. Nie jest jednak obojętne jaki w rodzinie panuje klimat emocjonalny, na jakich fundamentach jest ona wsparta i w jaki sposób jest zorganizowana ${ }^{12}$. W tym kontekście $\mathrm{z}$ jej wewnętrznym funkcjonowaniem wiąże się wiele problemów i zakłóceń, które mogą być katalizatorem do powstania zachowań problemowych u jej członków. Dotyczy to głównie młodych ludzi, podatnych w procesie socjalizacji na wpływ osób znaczących, gdzie jednym z mechanizmów nabywania zachowań jest uczenie się poprzez

\footnotetext{
12 Karolina Sigda i Renata Matusiak, „Dysfunkcjonalność współczesnej rodziny skutkiem różnego rodzaju uzależnień”, Społeczeństwo i Rodzina 46(2016), 1: 143-54.
} 
obserwację i naśladownictwo. Pozwala to na postawienie hipotezy o występowaniu związku międzypokoleniowej transmisji aktywności hazardowej i wpływie rodziny na jej charakter i rodzaj.

Ustalono, że $67 \%$ respondentów wychowywało się w rodzinach, gdzie osoby im najbliższe korzystały $\mathrm{z}$ różnych form hazardu. W większości przypadków gry te związane były albo z grami liczbowymi $(58,5 \%)$, albo z zawieraniem zakładów bukmacherskich $(32,2 \%)$ lub udziałem w loteriach i konkursach SMS-owych $(28,8 \%)$. Nieco mniejszą popularnością w domach badanych piłkarzy cieszyła się gra w karty na pieniądze $(27,5 \%)$, zakup zdrapek $(23,3 \%)$ oraz gra na automatach $(24,5 \%)$. Uprawiany hazard był głównie uskuteczniany przez osoby reprezentujące płeć męską. Najbardziej czynnymi w tym zakresie byli ojcowie, którzy swoje upodobanie do hazardu skupili wokół gier liczbowych $(42,2 \%)$, grze

Tabela 11. Gra bliskich osób piłkarzom w gry hazardowe w ich dzieciństwie

\begin{tabular}{|c|c|c|c|c|c|c|c|c|c|}
\hline \multicolumn{2}{|c|}{ Kategoria } & Ojciec & Matka & Brat & Siostra & Dziadek & Babcia & Inna bliska & Nikt \\
\hline \multirow{2}{*}{$\begin{array}{l}\text { Gra w gry } \\
\text { liczbowe }\end{array}$} & $\mathrm{Nie}$ & 57,8 & 75,5 & 93,7 & 94,8 & 83,7 & 87,3 & 88,7 & 41,5 \\
\hline & Tak & 42,2 & 24,5 & 6,3 & 5,2 & 16,3 & 12,7 & 11,3 & 58,5 \\
\hline \multirow{2}{*}{$\begin{array}{l}\text { Udział } \\
\text { w loteriach } \\
\text { SMS-owych }\end{array}$} & $\mathrm{Nie}$ & 90,9 & 86,6 & 96,2 & 96,7 & 97,8 & 97,1 & 91,1 & 28,8 \\
\hline & Tak & 9,1 & 13,4 & 3,8 & 3,3 & 2,2 & 2,9 & 9,9 & 71,2 \\
\hline \multirow{2}{*}{$\begin{array}{l}\text { Gra na } \\
\text { automatach }\end{array}$} & $\mathrm{Nie}$ & 93,3 & 98,6 & 91,3 & 98,9 & 98,9 & 99,4 & 91,3 & 24,5 \\
\hline & Tak & 6,7 & 1,4 & 8,7 & 1,1 & 1,1 & 0,6 & 9,7 & 75,5 \\
\hline \multirow{2}{*}{ Zdrapki } & $\mathrm{Nie}$ & 88,2 & 86,6 & 90,3 & 93,3 & 96,2 & 94,9 & 91,4 & 76,7 \\
\hline & Tak & 11,8 & 13,4 & 9,7 & 6,7 & 3,8 & 5,1 & 8,6 & 23,3 \\
\hline \multirow{2}{*}{$\begin{array}{l}\text { Gra w karty } \\
\text { na pieniądze }\end{array}$} & Nie & 88,9 & 98,7 & 91,9 & 99,3 & 95,9 & 99,7 & 89,4 & 27,5 \\
\hline & Tak & 17,1 & 1,3 & 8,1 & 0,7 & 4,1 & 0,3 & 10,6 & 72,5 \\
\hline \multirow{2}{*}{$\begin{array}{l}\text { Zakłady } \\
\text { bukmacher- } \\
\text { skie }\end{array}$} & $\mathrm{Nie}$ & 77,8 & 98,9 & 89,0 & 98,9 & 98,6 & 99,8 & 89,2 & 32,2 \\
\hline & Tak & 16,2 & 1,1 & 11,0 & 1,1 & 1,4 & 0,2 & 10,8 & 67,8 \\
\hline \multirow{2}{*}{$\begin{array}{l}\text { Gra na pie- } \\
\text { niądze } \\
\text { w Internecie }\end{array}$} & $\mathrm{Nie}$ & 96,4 & 99,3 & 94,8 & 99,5 & 99,7 & 99,8 & 93,3 & 16,1 \\
\hline & Tak & 3,6 & 0,7 & 5,2 & 0,5 & 0,3 & 0,2 & 6,7 & 83,9 \\
\hline \multirow{2}{*}{$\begin{array}{l}\text { Gra w kasy- } \\
\text { nie poza } \\
\text { Internetem }\end{array}$} & Nie & 97,8 & 99,7 & 97,1 & 99,5 & 99,4 & 99,7 & 91,4 & 11,3 \\
\hline & Tak & 2,2 & 0,3 & 2,9 & 0,5 & 0,6 & 0,3 & 8,6 & 88,7 \\
\hline \multirow{2}{*}{$\begin{array}{l}\text { Jakakolwiek } \\
\text { inna gra } \\
\text { na pieniądze }\end{array}$} & Nie & 94,9 & 98,9 & 96,2 & 99,7 & 98,9 & 99,7 & 92,8 & 16,3 \\
\hline & Tak & 5,1 & 1,1 & 3,8 & 0,3 & 1,1 & 0,3 & 7,2 & 83,7 \\
\hline
\end{tabular}

Źródło: Badania własne (N=583) 
w karty $(17,1 \%)$ oraz na zwieraniu zakładów bukmacherskich $(16,2 \%)$. Jeśli chodzi o kobiety ich ulubioną formą hazardu było wypełnianie kuponu gry liczbowej, zakup zdrapki lub udział w loteriach i konkursach SMS-owych. W tego rodzaju grach najczęściej brały udział matki badanych zawodników. Szczegółowy rozkład odpowiedzi podaje tabela 11 .

W ankietowanej grupie sportowców prawie 38\% piłkarzy dorastało w domach, w których nie tylko mogli obserwować jak ich najbliżsi uprawiają hazard, ale również mieli oni możliwość brania aktywnego udziału w ich grze - patrz tabela 12.

Tabela 12. Asystowanie przez badanych piłkarzy w dzieciństwie dorosłym podczas gier hazardowych

\begin{tabular}{|l|c|c|c|c|c|c|c|c|c|c|c|c|}
\hline & \multicolumn{10}{|c|}{ Stan cywilny } \\
\cline { 2 - 15 } & Kawaler & $\begin{array}{c}\text { W związku } \\
\text { nieformalnym }\end{array}$ & \multicolumn{2}{|c|}{ Żonaty } & \multicolumn{2}{c|}{ Wdowiec } & \multicolumn{2}{c|}{$\begin{array}{l}\text { Rozwodnik/ } \\
\text { separacja }\end{array}$} & \multicolumn{2}{c|}{ Ogółem } \\
\cline { 2 - 15 } & $\mathrm{N}$ & $\%$ & $\mathrm{~N}$ & $\%$ & $\mathrm{~N}$ & $\%$ & $\mathrm{~N}$ & $\%$ & $\mathrm{~N}$ & $\%$ & $\mathrm{~N}$ & $\%$ \\
\hline NIE & 216 & 59,5 & 65 & 17,9 & 74 & 20,4 & 0 & 0,0 & 8 & 2,2 & 363 & 100,0 \\
\hline TAK & 106 & 48,2 & 48 & 21,8 & 56 & 25,5 & 1 & 0,5 & 9 & 4,1 & 220 & 100,0 \\
\hline Ogółem & 322 & 55,2 & 113 & 19,4 & 130 & 22,3 & 1 & 0,2 & 17 & 2,9 & 583 & 100,0 \\
\hline
\end{tabular}

Źródło: Badania własne (Liczba badanych N=583)

Zwykle udział ten obejmował towarzyszenie osobie dorosłej $(18,7 \%)$ przy zakupie kuponu loteryjnego lub wybierania zdrapki i jej zdrapywaniu (16,8\%). Rzadziej aktywność ta obejmowała pomoc w typowaniu szczęśliwych liczb $(15,6 \%)$, na wrzucaniu pieniędzy do automatów $(7,9 \%)$ czy też asystowaniu podczas grania $\mathrm{w}$ grę hazardową w internecie $(3,1 \%)$. Szczegółowy rozkład odpowiedzi patrz tabela 13.

$\mathrm{Z}$ dokonanej analizy wynika równocześnie, że asystowanie w dzieciństwie dorosłym podczas ich gry hazardowej nie ma istotnego statystycznie związku $\mathrm{z}$ reprezentowanym obecnie stanem cywilnym przez badanych. Związek taki występuje w korelacji do zagrożenia uzależnieniem od hazardu. I tak osoby wykazujące umiarkowany poziom zagrożenia uzależnieniem od hazardu oraz osoby mające problem z hazardem statystycznie częściej niż osoby mające niski poziom zagrożenia uzależnieniem bądź wykazujące brak problemów uczestniczyły w dzieciństwie w grze hazardowej bliskich dorosłych. 
Tabela 13. Forma zaangażowania badanych piłkarzy w dzieciństwie w grę hazardową osób najbliższych

\begin{tabular}{|c|c|c|c|c|c|c|c|c|c|c|c|c|}
\hline \multirow{3}{*}{ Zaangażowanie } & \multicolumn{12}{|c|}{ Stan cywilny } \\
\hline & \multicolumn{2}{|c|}{ Kawaler } & \multicolumn{2}{|c|}{$\begin{array}{l}\text { W związku } \\
\text { nieformalnym }\end{array}$} & \multicolumn{2}{|c|}{ Żonaty } & \multicolumn{2}{|c|}{ Wdowiec } & \multicolumn{2}{|c|}{$\begin{array}{c}\text { Rozwodnik/ } \\
\text { separacja }\end{array}$} & \multicolumn{2}{|c|}{ Ogółem } \\
\hline & $\mathrm{N}$ & $\%$ & $\mathrm{~N}$ & $\%$ & $\mathrm{~N}$ & $\%$ & $\mathrm{~N}$ & $\%$ & $\mathrm{~N}$ & $\%$ & $\mathrm{~N}$ & $\%$ \\
\hline \multicolumn{13}{|c|}{ Pomoc w typowaniu liczb } \\
\hline NIE & 276 & 56,3 & 90 & 18,4 & 110 & 22,4 & 1 & 0,2 & 13 & 2,7 & 490 & 100,0 \\
\hline TAK & 46 & 49,5 & 23 & 18,0 & 20 & 20,7 & 0 & 0,2 & 2,7 & 4 & 93 & 100,0 \\
\hline Ogółem & 322 & 55,2 & 113 & 19,4 & 130 & 22,3 & 1 & 0,2 & 17 & 2,9 & 583 & 100,0 \\
\hline \multicolumn{13}{|c|}{ Towarzyszenie przy zakupie zakładów } \\
\hline NIE & 271 & 57,2 & 88 & 18,6 & 103 & 21,7 & 1 & 0,2 & 11 & 2,3 & 474 & 100,0 \\
\hline TAK & 51 & & 25 & & 27 & & 0 & & 6 & & 109 & 100,0 \\
\hline Ogółem & 322 & 55,2 & 113 & 19,4 & 130 & 22,3 & 1 & 0,2 & 17 & 2,9 & 583 & 100,0 \\
\hline \multicolumn{13}{|c|}{ Wybieranie zdrapek lub zdrapywanie kuponów } \\
\hline NIE & 275 & 56,7 & 92 & 19,0 & 102 & 21,0 & 1 & 0,2 & 15 & 3,1 & 485 & 100,0 \\
\hline TAK & 47 & 48,0 & 21 & 21,4 & 28 & 28,6 & 0 & 0,0 & 2 & 2,0 & 98 & 100,0 \\
\hline Ogółem & 322 & 55,2 & 113 & 19,4 & 130 & 22,3 & 1 & 0,2 & 17 & 2,9 & 583 & 100,0 \\
\hline \multicolumn{13}{|c|}{ Wrzucanie pieniędzy do automatu } \\
\hline NIE & 298 & 55,5 & 102 & 19,0 & 122 & 22,7 & 0 & 0,0 & 15 & 2,8 & 537 & 100,0 \\
\hline TAK & 24 & 52,2 & 11 & 23,9 & 8 & 17,4 & 1 & 2,2 & 2 & 4,3 & 46 & 100,0 \\
\hline Ogółem & 322 & 55,2 & 113 & 19,4 & 130 & 22,3 & 1 & 0,2 & 17 & 2,9 & 583 & 100,0 \\
\hline \multicolumn{13}{|c|}{ Towarzyszenie podczas grania $\mathrm{w}$ grę hazardową w internecie } \\
\hline NIE & 304 & 54,6 & 110 & 19,7 & 125 & 22,4 & 1 & 0,2 & 17 & 3,1 & 557 & 100,0 \\
\hline TAK & 18 & 69,2 & 3 & 11,5 & 5 & 19,2 & 0 & 0,0 & 0 & 0,0 & 26 & 100,0 \\
\hline Ogółem & 322 & 55,2 & 113 & 19,4 & 130 & 22,3 & 1 & 0,2 & 17 & 2,9 & 583 & 100,0 \\
\hline
\end{tabular}

Źródło: Badania własne (Liczba badanych N=583)

\section{WNIOSKI}

Hazard jest powszechną formą rozrywki w gronie zawodników IV ligi piłki nożnej makroregionu śląskiego. Badania udowadniają, że respondenci, reprezentujący tę kategorię sportowców, zdecydowanie częściej biorą udział w grach hazardowych niż robi to przeciętny Polak. W wyselekcjonowanej populacji do uprawiania hazardu w ciągu ostatnich 12 miesięcy poprzedzają- 
cych badanie przyznało się $71 \%$ ankietowanych sportowców w sytuacji, gdy dla ogółu Polaków w wieku 15+ odsetek ten wynosi $37,1 \%{ }^{13}$.

Piłkarze piątego szczebla rozgrywek należą do grupy podwyższonego ryzyka uzależnienia się od hazardu. Pomimo występującej stosunkowo dużej świadomości o możliwych negatywnych następstwach wynikających z uprawiania hazardu, w tę formę rozrywki systematycznie angażuje się co dziesiąty piłkarz a 12,6\% wśród grających wykazuje symptomy nałogowego uprawiania hazardu mierzone kwestionariuszem CPGI.

Czynnikiem, odgrywającym istotne znaczenie w rozwoju uzależnienia od hazardu, był wczesny kontakt ankietowanych piłkarzy z grami na pieniądze oraz międzypokoleniowa transmisja aktywności hazardowej w rodzinie. $67 \%$ piłkarzy, jako osoby małoletnie, doświadczało wokół siebie zaangażowania w gry hazardowe kogoś z najbliżej im rodziny. Zwykle był to ojciec, matka lub brat. Co trzeci z respondentów (38\%) nie tylko był biernym odbiorcą uprawiania gry hazardowej w jego rodzinie, ale także aktywnie uczestniczył w tego typu rozrywce dorosłych. Najczęstszą formą udziału było towarzyszenie przy zakupie losów oraz wybieranie zdrapek i ich zdrapywanie.

Z badań wynika, że osoby, które zawarły związek małżeński, mają bardziej wyważone opinie na temat hazardu od swych kolegów, którzy są stanu wolnego, rozwodnikami lub żyjącymi w związkach nieformalnych. Są również bardziej ostrożni w kwestii uprawiania hazardu i w efekcie w grupie tej występuje najniższy odsetek piłkarzy wykazujących problem z uzależnieniem od hazardu.

\section{BIBLIOGRAFIA}

CBOS, KBPN. Oszacowanie rozpowszechnienia oraz identyfikacja czynników ryzyka i czynników chroniacych hazardu i innych uzależnień behawioralnych - edycja 2018/2019. Warszawa: CBOS, KBPN, 2019.

Grall-Bronnec, Marie, Julie Caillon, Elise Humeau, Bastien Perrot, Manon Remaud, Alice Guilleux, Bruno Rocher, Anne Sauvaget, and Gaelle Bouju. „Gambling among European professional athletes. Prevalence and associated factors". Journal of Addictive Diseases 35(2016): 278-90, https://doi.org/10.1080/10550887.2016.1177807.

${ }^{13}$ CBOS, KBPN, Oszacowanie rozpowszechnienia oraz identyfikacja czynników ryzyka i czynników chroniacych hazardu i innych uzależnień behawioralnych - edycja 2018/2019 (Warszawa: CBOS, KBPN, 2019). 
Håkansson, Anders, Göran Kenttä, and Cecilia Åkesdotter. „Problem Gambling and Gaming in Elite Athletes". Addictive Behaviors Reports 8(2018): 79-84. https://doi.org/10.1016/j. abrep.2018.08.003.

Krzyżak-Szymańska, Ewa i Andrzej Szymański. Profilaktyka nowych uzależnień wśród dzieci i młodziezy. Zarys problematyki. Katowice: GWSH w Katowicach, 2013.

Lelonek-Kuleta, Bernadeta. „Uzależnienia behawioralne - podstawy teoretyczne”. W Uzależnienia behawioralne $i$ zachowania problemowe młodzieży, red. Jolanta Jarczyńska, 15-29. Bydgoszcz: Wydawnictwo Uniwersytetu Kazimierza Wielkiego, 2014.

Lelonek-Kuleta, Bernadeta. „Wiara w szczęśliwy los drogą do cierpienia? Patologiczny hazard w podejściu poznawczym". Horyzonty Psychologii 3(2013): 107-24.

Niewiadomska, Iwona, Weronika Augustynowicz, Agnieszka Palacz-Chrisidis, Michał Wiechetek, Joanna Chwaszcz i Rafał P. Bartczuk. Bateria metod stużacych do oceny ryzyka zaburzeń zwiazanych z hazardem. Lublin: Instytut Psychoprofilaktyki i Psychoterapii, Stowarzyszenie Natanaelum, 2014.

Perrotta, Giulio. „Pathological gambling disorder: definition, clinical contexts and therapeutic approaches". ES Journal of Neurology 1(2020): 1004.

Potenza, Marc N., Iris M. Balodis, Jeffrey Derevensky, Jon E. Grant, Nancy M. Petry, Antonio Verdejo-Garcia, and Sarah W. Yip. „Gambling Disorder”. Nature Reviews Disease Primers 5(2019): 51, https://doi.org/10.1038/s41572-019-0099-7.

Richard, Jeremie, Thomas S. Paskus, and Jeffrey Derevensky. „Trends in gambling behavior among college student-athletes: A comparison of 2004, 2008, 2012 and 2016 NCAA survey data”. Journal of Gambling Issues 41(2019): 73-100, http://dx.doi.org/10.4309/jgi.2019.41.5.

Rogier, Guyonne, Sara Beomonte Zobel, Andrea Marini, Jacopo Camponeschi, and Patrizia Velotti. "Gambling disorder and dissociative features: A systematic review and meta-analysis". Psychology of Addictive Behaviors 35(2021): 247-62, https://doi.org/10.1037/adb0000693.

Rowicka, Magdalena. Uzaleznienia behawioralne. Profilaktyka i terapia. Warszawa: Krajowe Biuro do Spraw Przeciwdziałania Narkomanii, Fundacja Praesterno, 2015.

Rutkowska, Emilia i Bernadeta Lelonek-Kuleta. „Robert Ladouceur's cognitive-behavioural conception of therapy for pathological gamblers". Psychoterapia 2(2018): 47-62.

Sigda, Karolina i Renata Matusiak. „Dysfunkcjonalność współczesnej rodziny skutkiem różnego rodzaju uzależnień". Społeczeństwo i Rodzina 46(2016), 1: 143-54.

Silczuk, Andrzej i Bogusław Habrat. „Zaburzenia uprawiania hazardu”. W Zaburzenia uprawiania hazardu i inne tak zwane natogi behawioralne, red. Bogusław Habrat, 83-218. Warszawa: Instytut Psychiatrii i Neurologii, 2016.

\section{UPRAWIANIE HAZARDU WŚRÓD PIŁKARZY ŚLĄSKIEJ IV LIGI A ICH STAN CYWILNY}

\section{St r e s z c z e n i e}

Badania stanowią opis uprawiania hazardu w grupie 583 piłkarzy grających w IV lidze śląskiego makroregionu. Celem badań było rozpoznanie udziału piłkarzy w uprawianiu hazardu oraz znalezienie odpowiedzi na pytanie, czy ze względu na posiadany stan cywilny sportowcy, będący w związkach formalnych, różnią się od piłkarzy nie będących w takich związkach w sposobie podejścia do gry. Badania przeprowadzono za pomocą autorskiego kwestionariusza ankiety, który 
poszerzono o Kanadyjski Indeks Gier Hazardowych CPGI. Otrzymane wyniki wskazują, że respondenci statystycznie częściej biorą udział w grze hazardowej niż przeciętny Polak w wieku powyżej 15 lat. Upodobaną formą gry wśród badanych zawodników był udział w obstawianiu zakładów bukmacherskich. Piłkarze należą do grupy podwyższonego ryzyka uzależnienia się od hazardu. Problem ten dotyczy ponad $12 \%$ przebadanych zawodników. Istotnym predykatorem uprawiania hazardu przez piłkarzy był ich aktywny kontakt z grą w dzieciństwie. Badania dowodzą, że zawodnicy, którzy zawarli związek małżeński, są bardziej ostrożni w uprawianiu hazardu od swoich kolegów żyjących w związkach nieformalnych lub będących stanu wolnego.

Słowa kluczowe: uzależnienia behawioralne; hazard;, piłkarze; stan cywilny. 